\title{
Detection of the presence of used frying oil as raw material in biodiesel production
}

\author{
By M.V. Ruiz Méndez*, A. Liotta, S. Marmesat and M.C. Dobarganes \\ Instituto de la Grasa (CSIC). Avda Padre García Tejero, 4. 41012 Sevilla \\ *Corresponding author: mvruiz@cica.es
}

\begin{abstract}
RESUMEN
Detección de la presencia de aceites de fritura como materia prima en la obtención de biodiesel

La detección de compuestos característicos de los aceites de fritura usados como materia prima de bajo coste en la obtención de biodiesel, es de interés para garantizar su calidad. En este estudio, se analizan los grupos de compuestos más característicos obtenidos tras la transesterificación de los aceites de fritura mediante la técnica estándar que utiliza cromatografía de gases a temperatura elevada (European Standard EN 14105). Los dímeros de ésteres metílicos son los compuestos más importantes para detectar el aceite de fritura como materia prima, debido a su presencia en cantidades significativas después de la transesterificación de los aceites de fritura y a su ausencia en los aceites decolorados que se utilizan en la obtención de biodiesel. La concentración de los dímeros en la fracción polar del biodiesel, fácilmente obtenida mediante cromatografía de adsorción, permite detectar los citados compuestos incluso a concentraciones muy bajas.
\end{abstract}

PALABRAS CLAVE: Aceites de fritura - Biodiesel - Cromatografía de adsorción - Dímeros - EN 14105.

\section{SUMMARY}

Detection of the presence of used frying oil as raw material in biodiesel production.

The detection of compounds giving information on the use of used frying oils as raw material in the production of biodiesel is of interest to guarantee the quality of the product. In this study, the most characteristic groups of compounds formed after used frying oil transesterification were analyzed by means of the standard technique using gas chromatography at a high temperature (EN 14105). Dimeric fatty acid methyl esters (dimeric FAME) is the most important group to be considered as they are present in significant amounts after used frying oil transesterification. On the other hand, they are absent in the bleached oils used for biodiesel production. The concentration of the dimeric FAME in the polar fraction of biodiesel, easily obtained by adsorption chromatography, allowed detection of this group of compounds even in very low concentrations.

KEY-WORDS: Adsorption chromatography - Biodiesel Dimers - EN 14105 - Used frying oils.

\section{INTRODUCTION}

Biodiesel is composed of monoalkyl esters of long-chain fatty acids derived from vegetable oils or animal fats and continues gaining interest around the world due to the increasing petroleum prices (Cerveró et al., 2008). With the growing use of biodiesel, the assurance of quality is necessary to guarantee the successful commercialization of biodiesel, in particular when used frying fats of low cost and poor quality are employed as raw materials. Accordingly, biodiesel standards have been established and new methods are being developed to improve the control of biodiesel quality (Knothe, 2006).

In a previous paper, the main analytical differences between unused oils and used frying oils were defined. Thus, the presence of significant amounts of degradation compounds due to the conditions of the frying process is unavoidable. In addition, there is a high heterogeneity in used frying oils as compared to crude or refined oils (Ruiz Méndez et al., 2008).

Determination of polar fatty acid methyl esters (FAME) by column chromatography was proposed as a good alternative to the standard GC method EN 14103 (European Standard, 2003a) due to both its accuracy and to the fact that no instrumental techniques are required. In general, biodiesels from used frying oils do not fulfil the ester content specification ( $96.5 \%$ minimum) as measured by the standard GC method and thus, they are used in mixtures with biodiesels obtained from unused oils. The regulation is established to guarantee a very high yield in the transesterification reaction limiting the presence of a significant amount of triglycerides and partial glycerides, which would affect its use as an automotive diesel fuel substitute. However, in the case of used frying fats, the main degradation compounds in biodiesels are esters (oxidized FAME and dimeric and oligomeric FAME) that do not elute in GC determination. Thus, detection of the presence of compounds from used frying oils in biodiesels is possible due to their different structure as compared to those present in unused oils.

Among the analytical procedures developed for both the determination of glycerol as well as for triglycerides and partial glycerides in biodiesel, the «Plank Method», by gas chromatography at a high temperature, has been adopted for the analysis of biodiesels due to its high accuracy in quantifying minor components and also because all the compounds of interest are obtained in the same analysis. It requires the hydroxyl groups of the 
sample to be derivatized by silylation before analysis and the use of internal standards (European Standard, 2003b). Under the conditions of high temperature applied for the separation, oxidized FAME and dimeric and trimeric FAME have volatility enough to elute and, consequently, their detection could be possible without modification of the standard method applied.

The objective of this study was to characterize the biodiesels obtained from used frying oils by detecting the presence of specific degradation compounds.

\section{MATERIALS AND METHODS}

\subsection{Chemicals}

Tricaprin, methyl cis-9,10-epoxystearate, methyl 12- ketostearate, methyl 12-hydroxystearate and methyl ricinoleate were purchased from Nu-CheckPrep. (Elysian, MN, USA). Silica gel 60 for column chromatography (particle size $0.063-0.100 \mathrm{~mm}$ ) was obtained from Merck (Darmstad, Germany). All other chemicals and reagents were of analytical grade and were obtained from local suppliers.

\subsection{Oil samples}

Crude rapeseed oil and used frying oil from domestic frying were used for biodiesel production. For obtaining the biodiesel, oils were sequentially degummed, neutralized, bleached and, finally, transesterified (See below). In addition to both samples, a mixture of biodiesel from rapeseed $(80 \%)$ and from used frying oil (20\%) was prepared.

\subsection{Oil treatment}

Degumming and Neutralization. Approximately $2.5 \mathrm{~kg}$ of crude oil was charged into a 5-liter, threenecked, round-bottomed stirred tank reactor. The tank reactor was fitted with an outlet in the lower part, a thermometer, and a stirring shaft with two stainless steel blades driven by a 120 rpm stirring motor. The device was connected to a vacuum pump for releasing the vapors.

The stirring motor was started, the oil temperature was brought to $40^{\circ} \mathrm{C}$ and $0.2 \%$ phosphoric acid was added. After $20 \mathrm{~min}$, the required amount of $20^{\circ}$ Bé (4.2 M) sodium hydroxide was added (volume of sodium hydroxide in liters to be added $=\mathrm{kg}$ of oil $\mathrm{x}$ acidity $x$ 0.85). The mixture were then stirred at 70 $\mathrm{rpm}$ and heated to $80^{\circ} \mathrm{C}$ for a maximum time of 35 min. When the mixture reached $70^{\circ} \mathrm{C}$ a brine solution $[10 \% \mathrm{NaCl}(\mathrm{w} / \mathrm{w})]$ was added in an amount equal to $75 \%$ of the volume of sodium hydroxide previously added. After stirring for $20 \mathrm{~min}$ at $70^{\circ} \mathrm{C}$, the soapstocks were separated from the refined oil by centrifugation (10 $\mathrm{min}$ at $3000 \mathrm{rpm})$. The oil was washed twice at $70^{\circ} \mathrm{C}$ with hot water in an amount equal to $10 \%$ by weight of oil. The contents were then heated to $90^{\circ} \mathrm{C}$, stirred at $95 \mathrm{rpm}$ for $10 \mathrm{~min}$, and the oil separated by centrifugation for $10 \mathrm{~min}$ at $3000 \mathrm{rpm}$.

Bleaching. The oil was dried by increasing the temperature to $90^{\circ} \mathrm{C}$ under 60 torr vacuum. After stirring for $15 \mathrm{~min}$ at $90^{\circ} \mathrm{C}, 1 \%$ by weight bleaching earth (Type C, Minas de Gador, Almería, Spain) was added. The oil was then heated to $110^{\circ} \mathrm{C}$, held at $110^{\circ} \mathrm{C}$ for 20 minutes with continuous stirring, filtered through filter paper (Esteryfil 123, Barcelona, Spain) in a laboratory filter press and allowed to cool.

Transesterification. The potassium hydroxide used as catalyst was dissolved into the alcohol by vigorous stirring in a small reactor. The proportion used was $0.35 \%$ and $20 \%$ by weight of the oil for the catalyst and methanol, respectively.

Approximately $2.5 \mathrm{~kg}$ of refined-bleached oil was charged into a stirred tank reactor and then the catalyst/alcohol mixture was pumped into the oil. The final mixture was stirred vigorously for 2 hours. A successful reaction produces two liquid phases: ester and crude glycerol. Crude glycerol, the heavier liquid, will be collected at the bottom after several hours of settling. Phase separation can be observed within 10 minutes and can be completed within 2 hours of settling. Complete settling can take as long as 20 hours. This step was carried out twice for completeness of the transesterification reaction. After settling was complete, water was added at the rate of 10 percent by volume of the oil, and then stirred for 5 minutes and the glycerol was allowed to settle again. Washing the ester was a two-step process.

\subsection{Analytical determinations}

Quantification of polar fatty acid methyl esters and their distribution in oligomeric, dimeric and oxidized monomeric FAME

Biodiesels were separated by silica column chromatography, using hexane/diethyl ether (95:5) to elute a nonpolar fraction including the nonpolar methyl esters, and diethyl ether to obtain the polar fraction including triglycerides, partial glycerides and fatty acids as well as oligomeric, dimeric and oxidized monomeric FAME (Dobarganes et al., 1984).

Analysis of the polar fraction was performed by HPSEC. The separation was performed on two 100 and $500 \AA$ Ultrastyragel columns $(25 \mathrm{~cm} \times 0.77 \mathrm{~cm}$ i.d.) packed with porous, highly cross linked styrene-divinylbenzene copolymers (film thickness: $10 \mu \mathrm{m})$ (Hewlett-Packard, Avondale, PA, USA) connected in series, with tetrahydrofuran (1 $\mathrm{mL} / \mathrm{min}$ ) as the mobile phase. The methodology was described in detail, including calibration and reproducibility data, in an earlier publication (Márquez-Ruiz et al., 1990). 
Determination of total and free glycerol, and mono- di- and triglycerides

These determinations were performed following the European Standard EN 14105 (European Union, 2003b). The standard determination was applied to the biodiesel samples as well as to the polar fractions obtained by adsorption chromatography by the technique described above Dobarganes et al. (1984). In the case of the analysis of polar FAME fractions, the total sample was used and the volume of the internal standard solution was proportional to that used for the total sample and depended on the sample weight.

Separations were performed on a HewlettPackard 5890 series gas chromatograph with cold on-column injection on a TBR 5 CB Low bleed/MS fused silica capillary column, $15 \mathrm{~m} \times 0.25 \mathrm{~mm}, 0.1 \mu \mathrm{m}$ (Teknokroma, Barcelona, Spain) and with detection by flame ionization detector. Hydrogen was used as a carrier gas at a column head pressure of $70 \mathrm{KPa}$ with the following oven temperature program: $50^{\circ} \mathrm{C}$ rising at $15^{\circ} \mathrm{C} \mathrm{min}{ }^{-1}$ to $155^{\circ} \mathrm{C}$ (held for $10 \mathrm{~min}$ ), then further heating at $7^{\circ} \mathrm{C} \mathrm{min}^{-1}$ to $210^{\circ} \mathrm{C}$ (held for 7 min) and finally heating at $15^{\circ} \mathrm{C} \mathrm{min}^{-1}$ to $340^{\circ} \mathrm{C}$ (held for $15 \mathrm{~min}$ ). A flame ionization detector was used at $350^{\circ} \mathrm{C}$.

\section{Other determinations}

Free fatty acids, oil stability index, peroxide value and fatty acid composition were determined following the AOCS standard methods (AOCS, 1995). Polar compounds and their distribution were carried out following the methodology proposed by Dobarganes et al. (2000). Tocopherols were quantified by HPLC and fluorescence detection following the IUPAC standard method (IUPAC, 1992)

\section{RESULTS AND DISCUSSION}

Table 1 shows the characteristics of the initial and pre-treated bleached oils. The main differences due to the pre-treatment of neutralization and bleaching were found for quality indexes, i.e. acidity, peroxide values and stability against oxidation although no differences were found for fatty acids and polar compounds. The great differences found for polar compounds between both oils are due to the frying process, as observed for the high content of polymers, the most characteristic compounds of the action of temperature in the presence of air (Steel et al., 2006). In general, most of the unused oils have polar compound levels lower than $5 \%$ while levels can be highly variable in used frying oils and their quantification is essential to predicting the quality of the biodiesel.

In Table 2, the physicochemical characteristics of the biodiesels obtained from bleached oils are presented. Determination of nonpolar FAME by adsorption chromatography is shown in the first row of the table. As can be observed, only the biodiesel from rapeseed oil fulfils the ester content specification (> 96.5\%) while the biodiesel from the used frying oil cannot be used unless it is mixed to increase the nonpolar ester content. Thus, in the case of these two samples, the mixture of $20 \%$ of biodiesel from used frying oil and $80 \%$ of biodiesel from rapeseed oil would fulfil the ester content specification.

No differences in free fatty acids, peroxide value and fatty acid composition were found in biodiesels with respect to those found for bleached oils (Table 1). Although a loss in the oil stability index (OSI) is normally found in biodiesels, the OSI was higher in the biodiesel from the used frying oil as compared to that of the bleached oil. The changes in the

Table 1

Physicochemical characteristics of the initial and bleached oils.

\begin{tabular}{|c|c|c|c|c|c|}
\hline \multirow{2}{*}{\multicolumn{2}{|c|}{ Analysis }} & \multicolumn{2}{|c|}{ Rapeseed oil } & \multicolumn{2}{|c|}{ Used frying oil } \\
\hline & & Initial & Bleached & Initial & Bleached \\
\hline \multicolumn{2}{|l|}{$\begin{array}{l}\text { Acidity } \\
\text { (\% oleic acid) }\end{array}$} & 1.7 & 0.2 & 1.2 & 0.2 \\
\hline \multicolumn{2}{|c|}{$\begin{array}{l}\text { Peroxide Value } \\
\text { (meq/kg) }\end{array}$} & 20.6 & 10.1 & 18.0 & 10.4 \\
\hline \multicolumn{2}{|l|}{$\begin{array}{l}\text { Rancimat test } \\
\left(\mathrm{h} \text { at } 100^{\circ} \mathrm{C}\right)\end{array}$} & 18.0 & 10.4 & 24.8 & 4.7 \\
\hline $\begin{array}{l}\text { Major } \\
\text { fatty } \\
\text { acids (\%) }\end{array}$ & $\begin{array}{c}16: 0 \\
16: 1 \\
18: 0 \\
18: 1 \\
18: 2 \\
18: 3\end{array}$ & $\begin{array}{c}5.3 \\
- \\
1.0 \\
62.0 \\
21.0 \\
8.8\end{array}$ & $\begin{array}{c}5.1 \\
- \\
1.1 \\
61.2 \\
20.7 \\
8.6\end{array}$ & $\begin{array}{c}15.2 \\
1.9 \\
1.7 \\
67.0 \\
9.2 \\
0.3\end{array}$ & $\begin{array}{c}14.3 \\
1.7 \\
2.3 \\
69.0 \\
10.0 \\
0.5\end{array}$ \\
\hline $\begin{array}{l}\text { Polar } \\
\text { Compounds* } \\
(\%)\end{array}$ & $\begin{array}{l}\text { Total } \\
\text { * TGP } \\
\text { oxTGM } \\
\text { DG }\end{array}$ & $\begin{array}{l}4.9 \pm 0.1 \\
0.1 \pm 0.0 \\
2.6 \pm 0.1 \\
1.2 \pm 0.1\end{array}$ & $\begin{array}{ll}1 & 5.3 \pm 0.5 \\
0 & 0.1 \pm 0.1 \\
1 & 3.4 \pm 0.4 \\
1 & 1.0 \pm 0.0\end{array}$ & $\begin{array}{r}21.4 \pm 0.6 \\
8.3 \pm 0.3 \\
7.2 \pm 0.5 \\
5.0 \pm 0.2\end{array}$ & $\begin{array}{rr}6 & 21.5 \pm 1.1 \\
3 & 8.7 \pm 0.4 \\
5 & 7.1 \pm 0.5 \\
2 & 4.7 \pm 0.4\end{array}$ \\
\hline
\end{tabular}

*TGP, triglyceride polymers; oxTGM, oxidized triglyceride monomers; DG, diglycerides

Table 2

Physicochemical characteristics of biodiesels from unused rapeseed oil and from used frying oil.

\begin{tabular}{|c|c|c|c|}
\hline \multicolumn{2}{|c|}{ Analysis } & $\begin{array}{l}\text { Biodiesel from } \\
\text { rapeseed oil }\end{array}$ & $\begin{array}{l}\text { Biodiesel from } \\
\text { used frying oil }\end{array}$ \\
\hline \multicolumn{2}{|c|}{ Non-polar FAME (\%) } & 97.8 & 93.0 \\
\hline \multicolumn{2}{|c|}{ Acidity ( $\%$ oleic acid) } & 0.2 & 0.2 \\
\hline \multicolumn{2}{|c|}{$\begin{array}{l}\text { Peroxide Value } \\
\text { (meq/kg) }\end{array}$} & 20.8 & 10.0 \\
\hline \multicolumn{2}{|l|}{$\begin{array}{l}\text { Rancimat test } \\
\left(\mathrm{h} \text { at } 100^{\circ} \mathrm{C}\right)\end{array}$} & 10.2 & 6.5 \\
\hline \multirow[b]{2}{*}{$\begin{array}{l}\text { Major fatty } \\
\text { acids }(\%)\end{array}$} & $\begin{array}{l}16: 0 \\
16: 1\end{array}$ & $\begin{array}{l}5.0 \\
-\end{array}$ & $\begin{array}{r}14.3 \\
1.8\end{array}$ \\
\hline & $\begin{array}{l}18: 0 \\
18: 1 \\
18: 2 \\
18: 3\end{array}$ & $\begin{array}{r}1.3 \\
62.0 \\
20.8 \\
8.7\end{array}$ & $\begin{array}{r}1.0 \\
69.7 \\
9.9 \\
0.5\end{array}$ \\
\hline
\end{tabular}


Table 3

Changes in tocopherols $(\mathrm{mg} / \mathrm{kg}$ ) from the initial oil to biodiesel.

\begin{tabular}{|c|c|c|c|c|c|c|}
\hline \multirow{2}{*}{ Tocopherol } & \multicolumn{3}{|c|}{ Rapeseed oil } & \multicolumn{3}{|c|}{ Used frying oil } \\
\hline & Initial & Bleached & Biodiesel & Initial & Bleached & Biodiesel \\
\hline$\alpha$ & 208 & 23 & 10 & 62 & 18 & $\operatorname{tr}$ \\
\hline$\beta$ & 40 & 14 & nd & nd & nd & nd \\
\hline$\gamma$ & 374 & 175 & 128 & $\operatorname{tr}$ & nd & nd \\
\hline$\delta$ & 9 & 12 & nd & nd & nd & nd \\
\hline
\end{tabular}

tr, traces; nd, non detected

concentration of natural antioxidants, i.e. tocopherols (Table 3) account for the lower stability of bleached oils as compared to those of their parent initial oils. However, they do not explain the differences between both bleached oils and their corresponding biodiesels as the tocopherol content in both biodiesels were lower than that found in the bleached oils. Changes in the stability against oxidation are difficult to foresee as they do not only depend on the concentration and type of antioxidants but also on the level of free fatty acids and partial glycerides, normally present in biodiesels.

Table 4 summarizes the composition of polar FAME in both biodiesels when analyzed by sizeexclusion chromatography. After complete oil transesterification, only oligomeric, dimeric and oxidized monomeric FAME are expected. Nevertheless, the presence of partial glycerides, fatty acids and even triglycerides (TG) in low amounts in the biodiesels cannot be excluded. When present, partial glycerides, fatty acids and triglycerides would coelute with different groups of modified FAME according to their molecular weight, as expressed in the table. Under these circumstances, the unreacted glycerides have to be quantified by means of the standard method EN 14105 by $\mathrm{GC}$ at a high temperature (European Standard, 2003b).

Figure 1 shows chromatograms corresponding to biodiesels from unused rapeseed oil $(A)$ and used frying oil (B) and obtained by the standard method EN 14105. For rapeseed oil biodiesel (A), the presence of minor amounts of monoglycerides (MG) and diglycerides (DG) can be observed besides the compounds normally present, namely FAME, fatty acids, sterols, etc.

As for the biodiesel from used frying oil, a more complex chromatogram was obtained particularly after the elution of the internal standard. Chromatograms for standards of oxidized fatty acids, i.e. epoxy-, keto- and hidroxyacids, indicated that, after silylation, oxidized monomeric FAME eluted between 18 and 25 min under the conditions of the analysis. These compounds are in significant amounts in used frying fats although minor amounts are also expected in unheated oils of low quality. Similarly, dimeric FAME isolated from used frying oils were silylated and their elution times ranged from 39 and $41 \mathrm{~min}$ (data not shown). Dimeric FAME are originated as a consequence of
Table 4

Total polar fatty acid methyl esters (FAME) and their distribution.

\begin{tabular}{lcc}
\hline \multicolumn{1}{c}{ Polar FAME (\%) } & $\begin{array}{c}\text { Biodiesel from } \\
\text { rapeseed oil }\end{array}$ & $\begin{array}{c}\text { Biodiesel from } \\
\text { used frying oil }\end{array}$ \\
\hline Total & $2.1 \pm 0.2$ & $6.9 \pm 0.4$ \\
$\begin{array}{l}\text { Oligomers + } \\
\text { Triglycerides }\end{array}$ & $<0.1$ & $1.0 \pm 0.3$ \\
$\begin{array}{l}\text { Dimers + Diglycerides } \\
\text { Oxidized monomers }+\end{array}$ & $0.4 \pm 0.1$ & $2.5 \pm 0.2$ \\
Fatty acids & $1.6 \pm 0.1^{*}$ & $3.4 \pm 0.2^{*}$ \\
\hline
\end{tabular}

* The peak also includes polar unsaponifiable matter

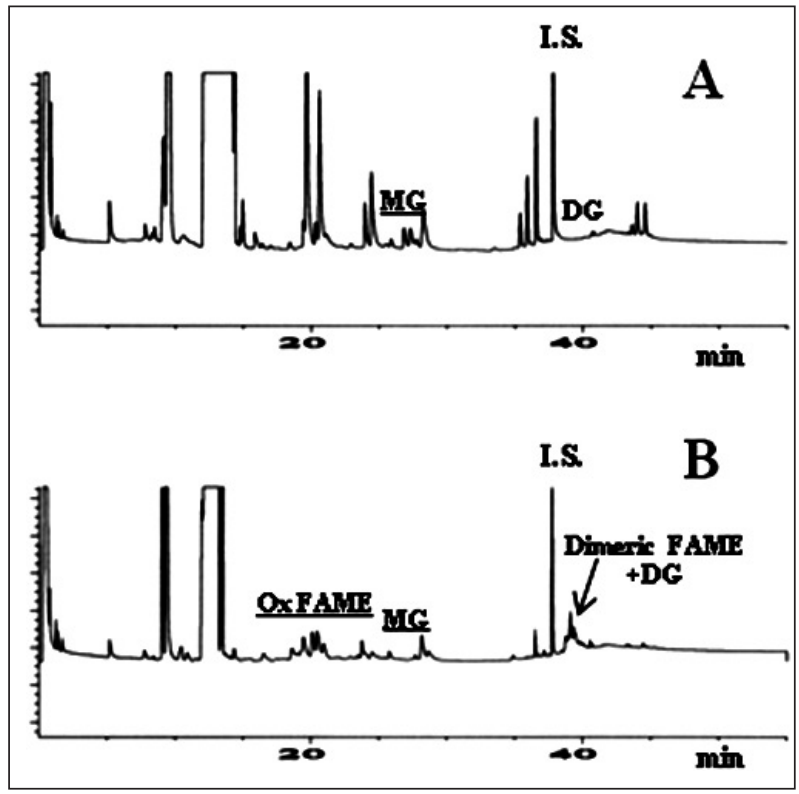

Figure 1

Chromatograms obtained following the standard method EN 14105 for biodiesels obtained from rapeseed oil $(A)$ and from used frying oil (B).

high temperature and, consequently, are not expected in biodiesels from crude or bleached oils. Thus, the presence of dimeric FAME is an important indication of the presence of used frying fats as raw material in the preparation of biodiesel. The two groups of modified FAME, i.e. oxidized monomeric FAME and dimeric FAME, can be easily observed in the chromatogram $B$ indicating that a frying oil was used for the preparation of the biodiesel. 


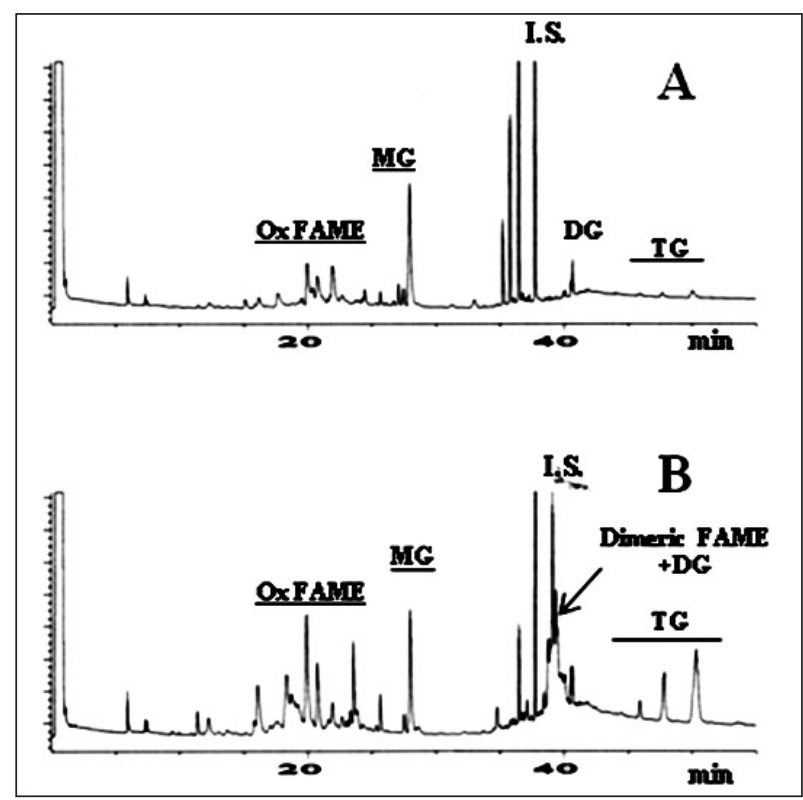

Figure 2

Chromatograms obtained following the standard method EN 14105 for the polar fraction of biodiesels obtained from rapeseed oil $(A)$ and from used frying oil $(B)$.

It is interesting to note that the separation of polar FAME by adsorption chromatography, allows the concentration of all the modified FAME and the unreacted material in the same fraction. Consequently, the analysis of the polar fraction instead of the total biodiesel enables to detect the presence of compounds coming from the used frying oil regardless of the concentration in the total sample. Chromatograms obtained for the polar fractions after separation of nonpolar FAME are shown in Figure $2 A$ and $B$ for rapeseed oil and used frying oil, respectively. As can be observed, the main peaks have disappeared and the concentration of dimeric FAME and oxidized monomeric FAME, both eluting as a group of peaks due to their complex composition, increased significantly. Also, TG can be observed in both samples, thus facilitating their quantitative determination.

Finally, figure 3 shows the advantages of nonpolar FAME elimination when the concentration of used frying oil is low. The figure shows chromatograms of a mixture 80:20 of the biodiesels from rapeseed oil and used frying oil, respectively, which fulfils the ester content specification $(96.8 \%$ calculated from the data in Table 2). In this mixture the level of polar compounds would be around $8.5 \%$ and the concentration of oxidized monomeric FAME and dimeric FAME is five times lower than that present in the biodiesel from used frying oil. Even in this sample corresponding to a used frying oil with a very low degradation level, a group of small peaks indicating dimeric FAME can be observed in the total sample (chromatogram A). However, if they were not detected, previous elimination of nonpolar FAME, would allow for their unambiguous detection as a group of peaks in the polar fraction (chromatogram B).

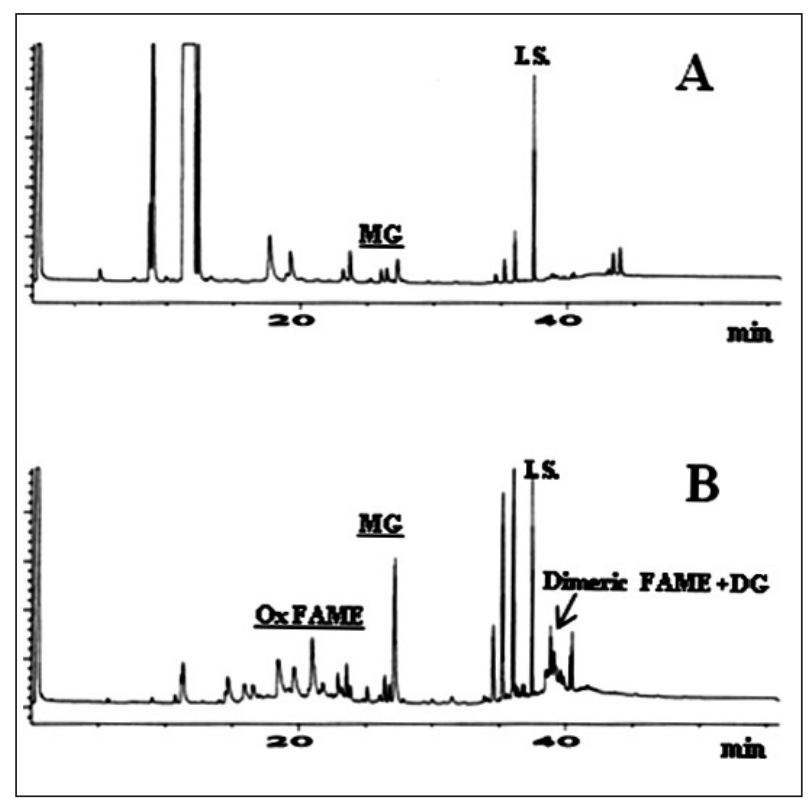

Figure 3

Chromatograms obtained following the standard method EN 14105 for the total biodiesel $(A)$ and its polar fraction (B) of the mixture of biodiesels obtained from rapeseed oil $(80 \%)$ and used frying oil (20\%).

\section{CONCLUSIONS}

The detection of used frying oil as raw material for biodiesels is possible by applying the standard method by GC at high temperatures used for the analysis of partial glycerides and triglycerides.

Dimeric FAME, always present in significant amounts after the tranesterification of used frying oils, is the most characteristic group of compounds to detect the presence of used frying oil as raw material in biodiesel production.

The analysis of polar fraction, after previous elimination of nonpolar FAME by adsorption chromatography, allows for the detection of dimeric FAME in biodiesel, even in very low concentrations.

\section{ACKNOWLEDGEMENT}

This work was funded by Ministerio de Ciencia y Tecnología (project AGR 2007-63647) and Junta de Andalucía. The authors thank $M$. Giménez for assistance.

\section{REFERENCES}

American Oil Chemists Society. 1995. Official Methods and Recommended Practices of the American Oil Chemists' Society. 5th Ed, Champaign, Illinois: AOCS Press

Cerveró JM, Coca J, Luque S. 2008. Production of biodiesel from vegetable oils. Grasas y Aceites 59, 76-83.

Dobarganes MC, Pérez-Camino MC, Gutiérrez GonzálezQuijano R. 1984. Métodos analíticos de aplicación en 
grasas calentadas. I. Determinación de ésteres metílicos no alterados. Grasas y Aceites 35, 172-177.

Dobarganes MC, Velasco J, Dieffenbacher A. 2000. The determination of polar compounds, polymerised triacylglycerols, oxidised triacylglycerols and diacylglycerols in fats and oils. Pure Appl. Chem. 72, 1563-1575.

European Standard EN 14103. 2003a. Fat and oil derivatives - Fatty Acid Methyl Esters (FAME) Determination of ester and linolenic acid methyl ester contents. European Committee for Standardization, Brussels, Belgium.

European Standard EN14105. 2003b. Fat and oil derivatives - Fatty Acid Methyl Esters (FAME) Determination of free and total glycerol and mono-, di-, triglyceride contents. European Committee for Standardization, Brussels, Belgium.

IUPAC. 1992. Standard methods for the analysis of oils, fats and derivatives. Standard Method 2.507International Union of Pure and Applied Chemistry. 1st supplement to 7th edition, Pergamon Press, Oxford

Knothe G. 2006. Analyzing biodiesel: Standards and other methods. J. Am. Oil Chem.Soc. 83, 823-833.

Márquez Ruiz G, Pérez-Camino MC, Dobarganes MC. 1990. Combination of adsorption and size-exclusion chromatography for the determination of fatty acid monomers, dimers and polymers. J. Chromatog. 514, 37-44

Ruiz Méndez MV, Marmesat S, Liotta A, Dobarganes MC. 2008. Analysis of used frying fats for biodiesel production. Grasas y Aceites 59, 45-50.

Steel CJ, Dobarganes MC, Barrera-Arellano D. 2006. Formation of polymerization compounds during thermal oxidation of cottonseed oil, partially hydrogenated cottonseed oil and their blends. Grasas y Aceites 57, 284-291. 